\title{
Eliminate the role of clay in sandstone: EOR low salinity water flooding
}

\author{
Hasan N. Al-Saedi ${ }^{1,2} \cdot$ Ralph E. Flori $^{1} \cdot$ Soura K. Al-Jaberi ${ }^{2}$
}

Received: 22 February 2018 / Accepted: 9 September 2018 / Published online: 20 September 2018

(c) The Author(s) 2018

\begin{abstract}
Low-salinity (LS) water flooding mechanism enhanced oil recovery (EOR) method in sandstone has been extensively debated in the literature. Many mechanisms have been proposed, but these proposed mechanisms remain a topic of debate. In this study, we propose to quantify control of mineral composition and water chemistry on water/rock interactions and wettability change during low-salinity waterflooding of spatially heterogeneous sandstone porous media. We intended to identify the dominant process of wettability alteration through considering water-rock interaction mechanisms containing/ non-containing clays. Water chemistry partially determines the dominant wettability alteration. This includes salinity, type of ions, and possibly $\mathrm{pH}$. Sandstone core and free clay sand core were prepared in chromatography columns and were water flooded with high/low/high-salinity water at different temperatures. Brine with high salinity 100,000 ppm was injected to simulate formation water, then, inflow low-salinity water $1100 \mathrm{ppm}$ at different temperatures. Concentrations of $\mathrm{Ca}^{2+}$ and $\mathrm{CH}_{3} \mathrm{COO}^{-}$and $\mathrm{pH}$ were recorded. The core contains quartz only, to investigate the role of clay in the mechanism of smart water EOR. The results proved that during flooding the free clay core by low-salinity water the carboxylic acid detached from the sand, albeit not as great as that of the clay-containing cores. On the other hand, ICP-OES showed a noteworthy desorption of $\mathrm{Ca}^{2+}$ from the free clay core surface. That indicates further $\mathrm{RCOO}^{-}$recovery in the absence of clay. It has been observed that during flooding by LS water, the $\mathrm{pH}$ increased significantly. Also, as the temperature increased the $\mathrm{pH}$ of the LS water decreased and amount of $\mathrm{Ca}^{2+}$ decreased in the effluent. This work presents the results of forced imbibition experiments to examine the effect of clay in sandstone during LS flooding EOR.
\end{abstract}

Keywords LSWF $\cdot$ Cation desorption $\cdot$ Geochemistry $\cdot$ EOR

\section{Introduction}

Field pilots and laboratory tests conducted on sandstone have shown that incremental oil recovery can be attained by injecting low-salinity water. The mechanisms behind incremental oil recovery by low-salinity water are controversial. The suggested mechanisms of enhancing oil recovery/wettability alteration in sandstones include: mineral dissolution (Aksulu et al. 2012), multi-component ion exchange (Lager et al. 2008a, b), double-layer expansion (Ligthelm et al. 2009), desorption of organic material from clay surfaces (Austad et al. 2010), reduction in interfacial tension

Hasan N. Al-Saedi

hnav36@mst.edu

1 Deptartment of Geosciences and Geological and Petroleum Engineering, Missouri University of Science and Technology, Rolla, MO 65401, USA

2 Missan Oil Company, Missan, Amara 62001, Iraq
(McGuire et al. 2005), and fines migration (Tang and Morrow 1999). Production apparently depends on the presence of clays in the reservoir (Lager et al. 2008a, b; Ligthelm et al. 2009; Austad et al. 2010; McGuire et al. 2005; Tang and Morrow 1999). The chemical composition of the injected water is another controlling parameter (Austad et al. 2010; Rezaeidoust et al. 2009; RezaeiDoust et al. 2011). However, there is no consensus on the dominant recovery mechanism (Austad et al. 2010; RezaeiDoust et al. 2011; Nasralla et al. 2013). This may be because several simultaneous processes contribute to the overall process. To our knowledge, no systematic experimental and numerical studies have been carried out that consider the most important water-rock interactions in sandstones simultaneously.

Reservoir chemical heterogeneity may also play a role. Experimental and field scale projects indicate that incremental oil recovery by low-salinity (LS) water flooding vary significantly case-by-case in both carbonates (Zhang et al. 2007; Yousef et al. 2012) and sandstones (McGuire et al. 
2005; Lager et al. 2008b). Minerals in natural porous media are typically distributed unevenly with random spatial patterns, ranging from uniform distribution to clustered minerals (Barber et al. 1992; Zinn and Harvey 2003). On one hand, physical heterogeneity changes flow fields and, therefore, spatial distribution of ions (Heidari and Li 2014). On the other hand, chemical heterogeneity significantly changes mineral dissolution rate (Salehikhoo et al. 2013; Li et al. 2014) and adsorption/desorption (Wang and Li 2015). Combination of physical and chemical heterogeneity can significantly impact water-rock interaction and wettability alteration. However, the effect of spatial distribution of reservoir physical and chemical properties on water-rock interaction and wettability alteration during LS water flooding has not been fully considered.

It was believed that the adsorption/desorption of organic materials occurred only on the negative sites of the clays in sandstone (Austad et al. 2010; RezaeiDoust et al. 2011; Fogden 2012). The experimental observations of Tang and Morrow (Austad et al. 2010) suggested conditions for chemical mechanisms for enhanced oil recovery by LS water flooding, those conditions are: (1) clay must exist in the sandstone core and (2) crude oil must contain organic materials. Lager et al. (2006) add another condition which was (3) active ions such as $\mathrm{Ca}$ and $\mathrm{Mg}$ must present in the formation water. In this study, we investigate the role of the clay in the sandstone and its effect on LS water enhanced oil recovery (EOR).

We examine the mechanism(s) of LS waterflooding in sandstone with and without clays as a function of temperature using three chromatographic columns containing different percentages of quartz and clays. The columns were flooded with high-salinity (HS) brine ( 100,000 ppm) until a constant $\mathrm{pH}$ was noted. The injecting water was then exchanged to LS water ( $1000 \mathrm{ppm})$. The effluent was collected for $\mathrm{Ca}^{2+}$ and $\mathrm{CH} 3 \mathrm{COO}^{-}$chemical analyses.

\section{Methodology}

\section{Materials}

\section{Column packing}

Chromatography columns were packed with quartz for the sand column and with quartz and clays for sandstone column. To avoid air bubbles in the column, which can change the hydraulic conductivity, wet packing was done (Minyard and Burgos 2007). The connections to the column ports were configured with a fine filter to prohibit mineral grains moving out of the column (Fig. 1).
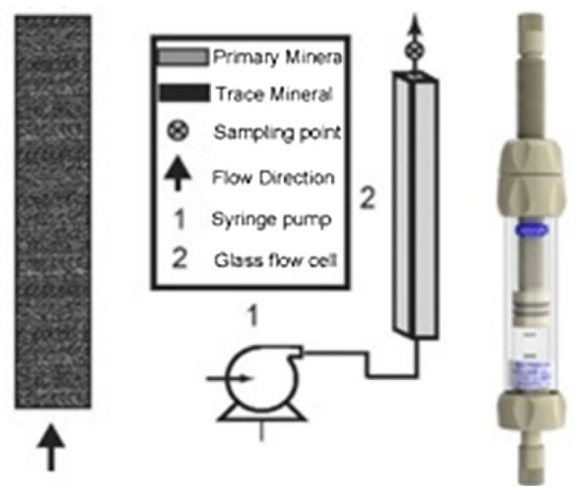

Fig. 1 Flow cell schematic

Table 1 Brine composition (PPM)

\begin{tabular}{lll}
\hline Element & HS & LS \\
\hline $\mathrm{Na}^{+}$ & 35,000 & 350 \\
$\mathrm{Cl}^{-}$ & 60,000 & 600 \\
$\mathrm{Ca}^{2+}$ & 4500 & 0 \\
Acetate & 820 & 0 \\
TDS & 98.32 & 1.182 \\
Salinity & $\sim 100,000$ & $\sim 1000$ \\
\hline
\end{tabular}

\section{Brines}

Two kinds of brine were used in this study, HS and LS water. HS brine was prepared by liquefying reagent $\mathrm{CaCl}_{2}$ and $\mathrm{NaCl}$ in deionized water, and LS water was prepared by dissolving reagent $\mathrm{NaCl}$ in deionized water. Brine compositions are listed in Table 1.

\section{Experimental procedure}

\section{Column water flooding in the presence of acetate}

The column was flushed by HS water and then aged for a week at $70{ }^{\circ} \mathrm{C}$ with the same HS water containing $10 \mathrm{mmole}$ sodium acetate. This was done to maximize sorption of carboxylic material to the surface of the rock so as to simulate bonding of oil-bound carboxylic material to a reservoir. The system was then flooded with HS water until the $\mathrm{pH}$ stabilized. Brines were pumped upward from the bottom of the columns using a syringe pump. Aqueous samples were collected at the column outlet for later analysis of ionic concentrations. After each experiment, the column was aged at the same condition for a week to restore the sample to the initial conditions. The whole system was operated inside an oven set to the temperature of interest (Table 2). 
Table 2 Description of the columns

\begin{tabular}{lccllll}
\hline Quartz $(\%)$ & Illite $(\%)$ & Kaolinite $(\%)$ & $D(\mathrm{~cm})$ & $L(\mathrm{~cm})$ & $K(\mathrm{md})$ & $\Phi(\%)$ \\
\hline 100 & 0 & 0 & 1.5 & 6.3 & 600 & 33.6 \\
80 & 20 & 0 & 1.5 & 6.3 & 301 & 33.24 \\
80 & 0 & 20 & 1.5 & 6.3 & 65 & 33.02 \\
\hline
\end{tabular}

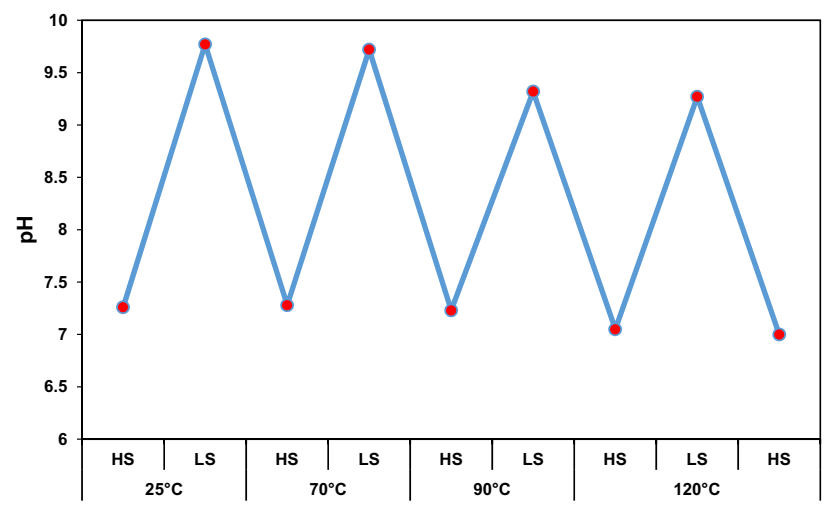

Fig. 2 Effluent $\mathrm{pH}$ from sand column, at $25,70,90$, and $120^{\circ} \mathrm{C}$

\section{Chemical analysis}

$\mathrm{Ca}^{+2}$ concentrations were measured using (2000D ICPOES). Effluent acetate concentrations were measured using a Dionex DX-120 ion chromatography setup.

\section{Oil recovery test}

The same columns were flushed and saturated with HS water and then flooded with crude oil and aged for a week at $70{ }^{\circ} \mathrm{C}$. HS water then injected into the column followed by LS water and oil recovery was observed from the effluent.

\section{Results and discussion}

\section{Sand column}

This column was $100 \%$ quartz. At $25^{\circ} \mathrm{C}$ (Fig. 2), the pH was 7.26 when flooded with high-salinity water. Upon switching to LS water the $\mathrm{pH}$ rose to $\mathrm{pH} 9.77$. When the injected water was transferred to the original HS water, the $\mathrm{pH}$ fell back to 7.29 . There was about a $2.5 \mathrm{pH}$ difference between HS water effluent $\mathrm{pH}$ and $\mathrm{LS}$ water effluent $\mathrm{pH}$. The upward shift in effluent $\mathrm{pH}$ difference between HS and LS water is traditionally ascribed to the exchange of $\mathrm{H}^{+}$for $\mathrm{Ca}^{2+}$ on clay surfaces (Lager et al. 2006). We observe the same trend in the absence of clay and ascribe it to $\mathrm{H}^{+}$exchange for $\mathrm{Ca}^{2+}$ and $\mathrm{Na}^{+}$sorbed to negatively charged quartz surface sites.

At $70{ }^{\circ} \mathrm{C}$, the $\mathrm{pH}$ for the HS water effluent was 7.28. The water then switched to the LS water and $\mathrm{pH}$ for the LS water effluent was 9.72. After that, switching the flooding to the original HS water stabilized the $\mathrm{pH}$ back to its original value. An important variance 2.44 in $\mathrm{pH}$ between $\mathrm{HS}$ water and LS water effluents was observed. The $\mathrm{pH}$ trend is about the same at $90{ }^{\circ} \mathrm{C}$. The $\mathrm{pH}$ stabilized at 7.23 while flooding the column by HS water, after switching to LS water the $\mathrm{pH}$ increased directly and stabilized at 9.32. The injected fluid switched again to the original $\mathrm{HS}$ water and $\mathrm{pH}$ return to its original value. At $120^{\circ} \mathrm{C}$, the $\mathrm{pH}$ initially was 7.15 when flooded Column 1 by HS water. The $\mathrm{pH}$ suddenly rose and stabilized at $9.20 \mathrm{pH}$ unit when switching the flooding to LS water. The injected fluid then switched again to the same HS water, and the $\mathrm{pH}$ fluctuated until fell again to its original value.

At all temperatures, evidence for $\mathrm{Ca}^{2+}$ desorption is seen in Fig. 3. It does not appear to be a clear trend after $90{ }^{\circ} \mathrm{C}$. As can be seen from (Table 1) that LS water has no $\mathrm{Ca}^{2+}$.

The desorbed $\mathrm{Ca}^{2+}$ in the exchanger attributed to the ion exchange of $\mathrm{Ca}^{2+}$ with $\mathrm{H}^{+}$and $\mathrm{Na}^{+}$on the negative surface site of quartz. Figure 4 shows effluent acetate profiles from cores that were aged in HS water containing $10 \mathrm{mmole}$ sodium acetate for a week at $70{ }^{\circ} \mathrm{C}$ (Fig. 5).

Again, core aging in acetate was done to maximize sorption of carboxylic material to the surface of the rock to simulate the bonding of oil-attached carboxylic groups to reservoir surfaces. It should be noted that Fig. 4 is plotted for the whole pore volumes that were injected to clarify the total volume that injected into the Sand Column. Figure 4 shows a lack of correlation between increasing temperature and detachments of carboxylic materials when flooding the column by HS and LS water. As can be noticed, the detachment of $\mathrm{RCOO}^{-}$was higher at $25^{\circ} \mathrm{C}$ than at $70{ }^{\circ} \mathrm{C}$ which was less than what was observed at $90{ }^{\circ} \mathrm{C}$ and the least detachment was at $120^{\circ} \mathrm{C}$. However, a significant carboxylic material was produced when switched the fluid to LS water especially at $25^{\circ} \mathrm{C}$ and $90^{\circ} \mathrm{C}$.

In conclusion, it is obvious that quartz surface and carboxylic materials are both negatively charged, so carboxylic materials repelled from the quartz surface. Indeed, the carboxylic material bonded with multivalent cation $\mathrm{Ca}^{2+}$ $\left[-\mathrm{COOCa}^{+}\right]\left[>\mathrm{SiO}_{2}-\right]$ in form of electrostatic bridging with quartz surface. When LS water invaded the porous media, an ion exchange takes place then organic complexes removed and replaced with uncomplexed cations providing a more water wet environment and in turn enhancing recovery. In another word, when LS water invaded sand 

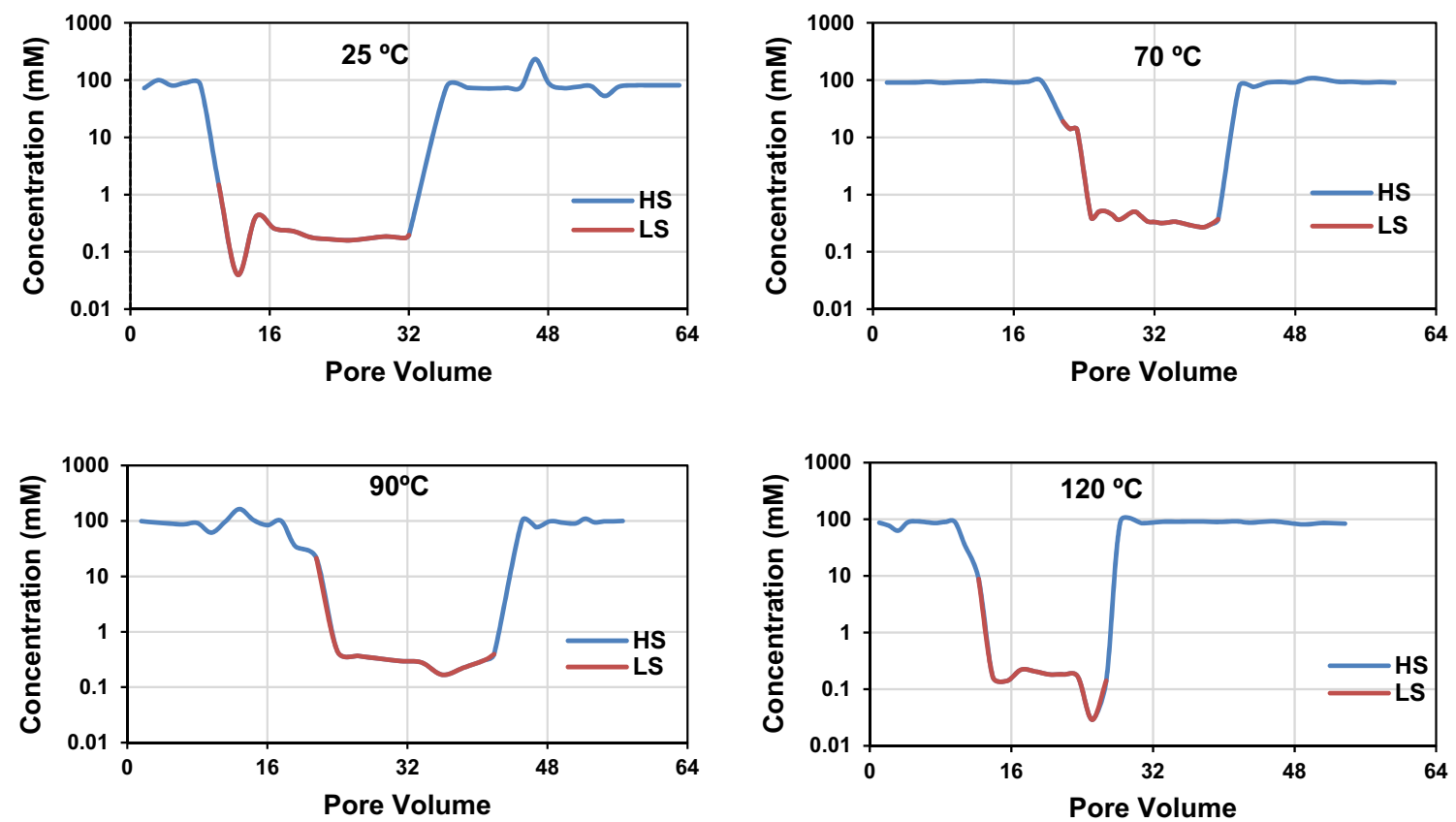

Fig. 3 Effluent concentrations of $\mathrm{Ca}^{2+}$ from sand column at $25,70,90$, and $120{ }^{\circ} \mathrm{C}$
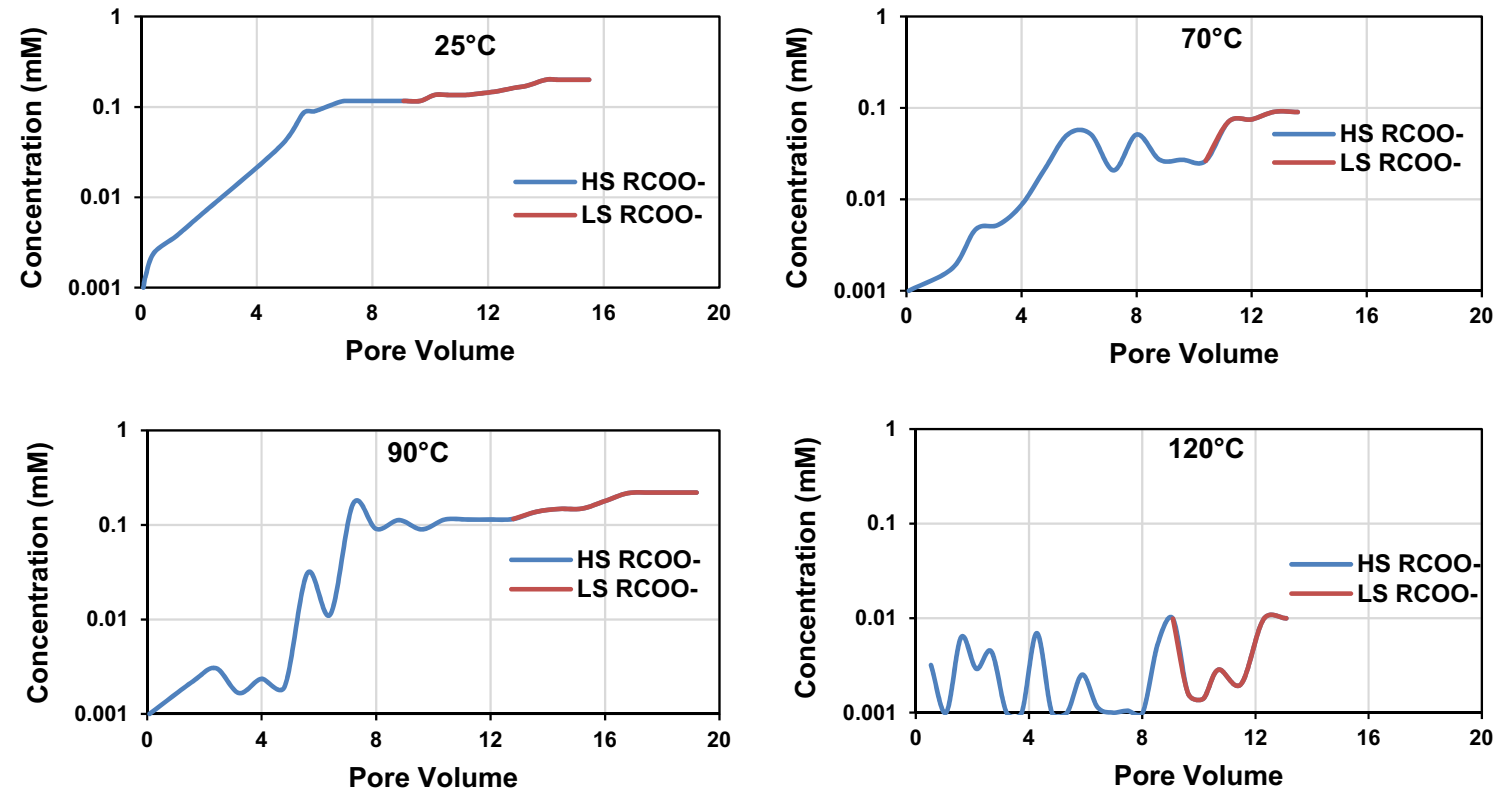

Fig. 4 Concentrations of $\mathrm{RCOO}^{-}$in first HS and LS water effluent at 25, 70, 90, and $120^{\circ} \mathrm{C}$

column, the electrostatic attraction between the linked carboxylic on $\mathrm{Ca}^{2+}\left[-\mathrm{COOCa}^{2+}\right]$ and $\left[>\mathrm{Si}-\mathrm{O}_{2}{ }^{-}\right]$became very weak and the recovery increased. A quite clear correlation observed for the $\mathrm{pH}$ gradient, as the temperature increased the $\mathrm{pH}$ gradients decreased. The gradients of $\mathrm{pH}$ were $2.51,2.44,2.09$, and 2.04 at $25,70,90$, and $120^{\circ} \mathrm{C}$, respectively. ICP-OES shows that about $0.32,0.37,0.32$, and $0.16 \mu$ mole $\mathrm{Ca}^{2+}$ desorbed from silicate surface at 25 , 


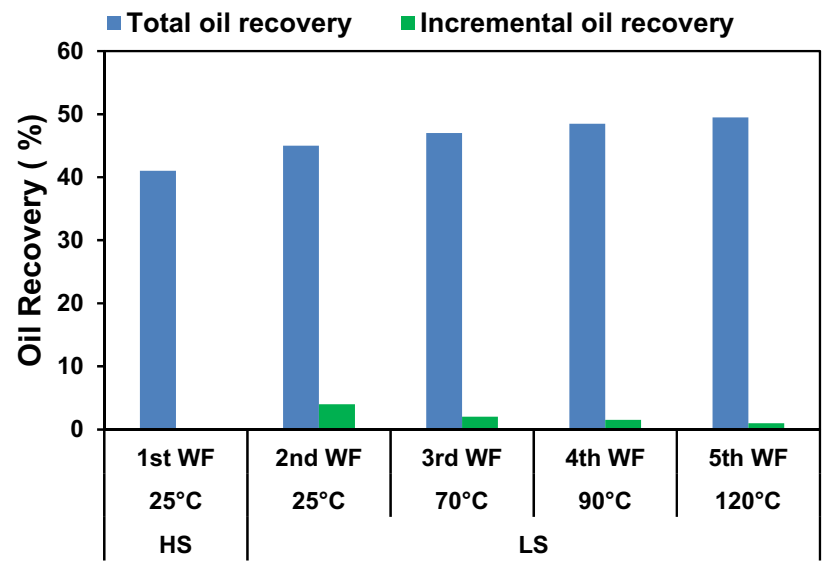

Fig. 5 Oil recovery test for sand column

70,90 , and $120^{\circ} \mathrm{C}$, respectively, when the flooding fluid switched to LSW effluent (Fig. 3). A significant amount of $\mathrm{RCOO}^{-}$was produced when the water switched from HS to LS water. The acetate release was $10.60 \%, 8.35 \%, 3.80 \%$ at $25,70,90^{\circ} \mathrm{C}$, respectively, while the recovery curve was not stable at $120^{\circ} \mathrm{C}$ (Fig. 4). This is a good evidence of how LS water improved the carboxylic acid detachment in sandstone without clay. The obtained results for $\mathrm{Ca}^{2+}$ desorption and $\mathrm{RCOO}^{-}$detachment were in line with our expectations. The following reactions explain the ion exchange on the sand surface:

$$
\begin{aligned}
& \mathrm{SiO}_{2}-\mathrm{Ca}^{2+}+\mathrm{H}_{2} \mathrm{O} \leftrightarrow \mathrm{SiO}_{2}-\mathrm{H}^{+}+\mathrm{Ca}^{2+}+\mathrm{OH}^{-}, \\
& >\mathrm{Na}+\mathrm{H}^{+} \leftrightarrow>\mathrm{H}^{+}+\mathrm{Na}^{+} .
\end{aligned}
$$

\section{Oil recovery test (sand column)}

The column was initially flooded by HS water at $25^{\circ} \mathrm{C}$ until no oil recovery in the effluent; the oil recovery factor was $41 \%$ OOIP. The injected fluid then switched to LS water and the incremental oil recovery was $4 \%$ OOIP at $25^{\circ} \mathrm{C}$. The incremental oil recovery was $2,1.5$, and $1 \%$ OOIP at 70,90 , and $120^{\circ} \mathrm{C}$, respectively.

\section{Sandstone column\#1 (sand + illite)}

The $\mathrm{pH}$ trend during flooding this column was approximately the same as quartz column (Fig. 6). The pH of HS water was around 7 , and as the temperature increases, the $\mathrm{pH}$

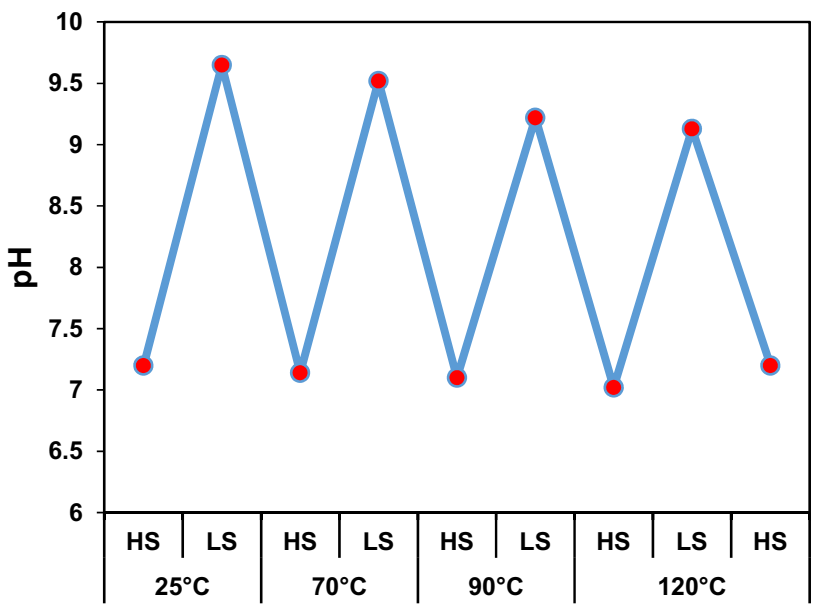

Fig. 6 Effluent pH from sand column\#1 (sand+illite), at 25, 70, 90, and $120^{\circ} \mathrm{C}$

decreases. Upon switching to $\mathrm{LS}$ water, the $\mathrm{pH}$ jumped to $9.65,9.52,9.22$, and 9.13 at $25,70,90$, and $120^{\circ} \mathrm{C}$, respectively. The $\mathrm{Ca}^{2+}$ measurements from the effluent were performed the same way as in sand column, and the results were in line with the sand column. $\mathrm{Ca}^{2+}$ desorption occurred at all temperatures (Fig. 7). Acetate detachments were also approximately the same as in sand column (a little higher than the sand column) (Fig. 8), supported our theory about eliminating the clay role.

\section{Oil recovery test (sandstone column\#1)}

The same procedure was conducted as in oil recovery test for sand column. The ultimate oil recovery during HS flooding was $42.23 \%$ OOIP at ambient temperature. Upon switching to LS water, the incremental oil recovery was 3.2, $2.3,2$, and $0.5 \%$ OOIP at $25,70,90$, and $120^{\circ} \mathrm{C}$, respectively (Fig. 9).

\section{Sandstone column\#2 (sand + kaolinite)}

The measurements $\mathrm{Ca}^{2+}$ desorption and acetate detachments from quartz and clay surfaces were in line with the two previous columns. Normally, $\mathrm{pH}$ decreased with the temperature increase except for this column. An increase in $\mathrm{pH}$ of the LS water effluent took place after switching to LS water due to the buffering effect of the high concentration 

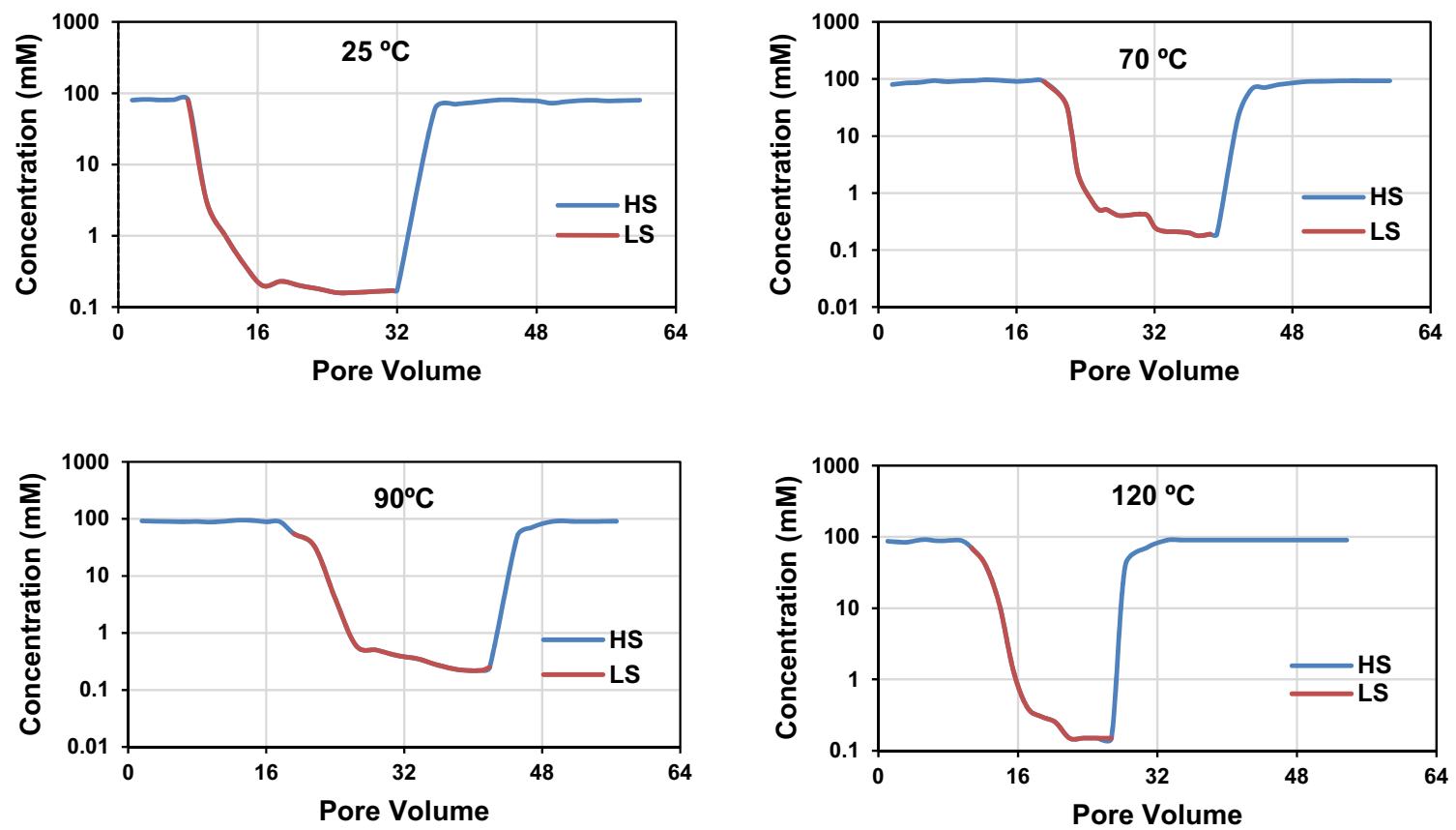

Fig. 7 Effluent concentrations of $\mathrm{Ca}^{2+}$ from sandstone column\#1 (sand +illite), at $25,70,90$, and $120{ }^{\circ} \mathrm{C}$

of desorbed $\mathrm{Ca}^{2+}$ in sandstone column\#2, which causes a local increase in $\mathrm{pH} \mathrm{Ca}{ }^{2+}+\mathrm{OH}^{-} \leftrightarrow(\mathrm{Ca}-\mathrm{OH})^{+}$(RezaeiDoust et al. 2011). Figures 10, 11 and 12 show the results of $\mathrm{pH}$ measurements, $\mathrm{Ca}^{2+}$ desorption, and detachment of the acetate.
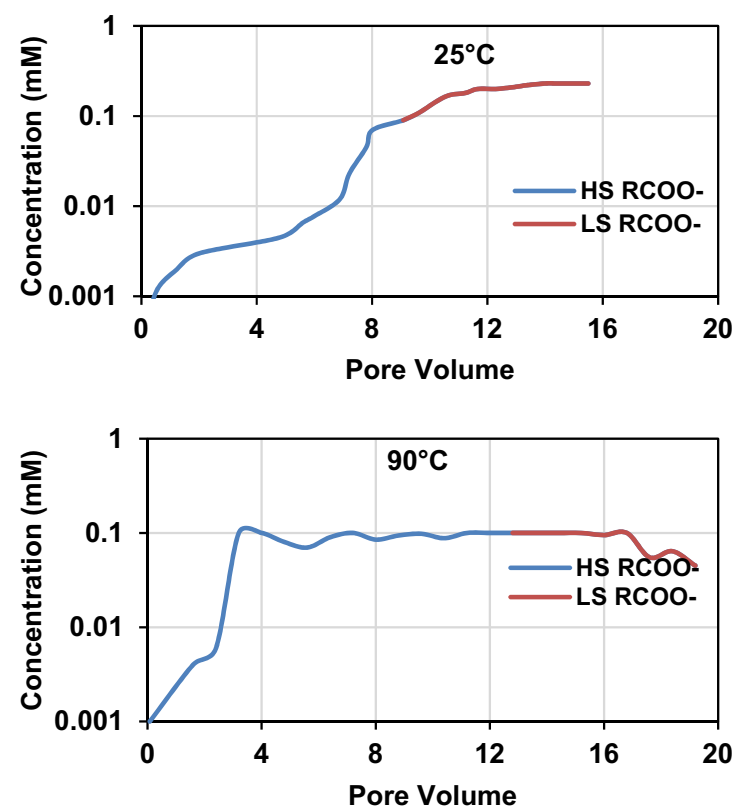

\section{Oil recovery test (sandstone column\#2)}

The ultimate oil recovery was $40.35 \%$ OOIP after the column flooded with HS water. The recovery improved to $4.1,1.9,1.55$, and $1 \%$ OOIP after flooding the column with LS water at $25,70,90$, and $120^{\circ} \mathrm{C}$, respectively.
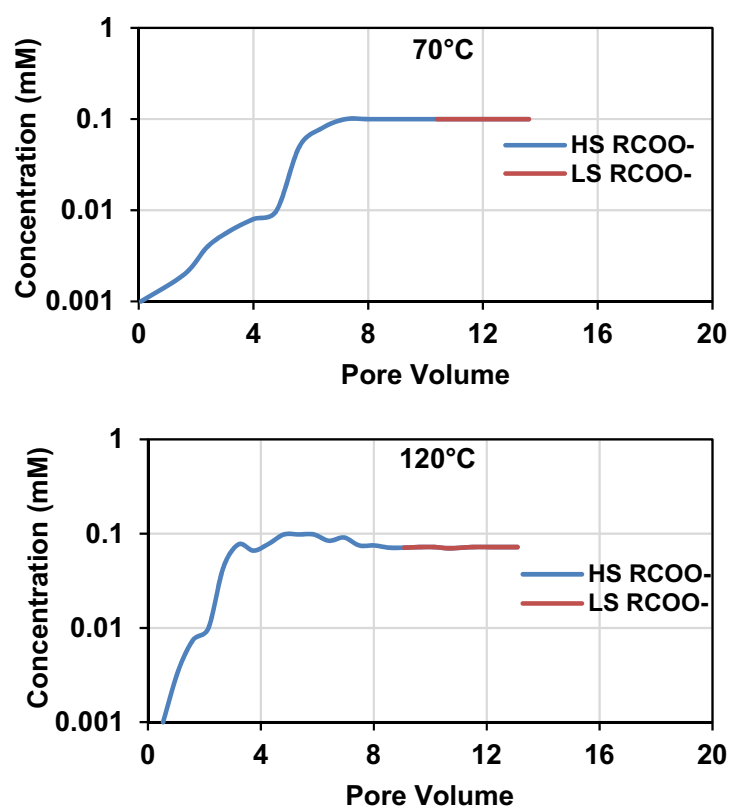

Fig. 8 Concentrations of $\mathrm{RCOO}^{-}$in first $\mathrm{HS}$ and LS water effluent for sandstone column\#1 (sand + illite), at $25,70,90$, and $120{ }^{\circ} \mathrm{C}$ 


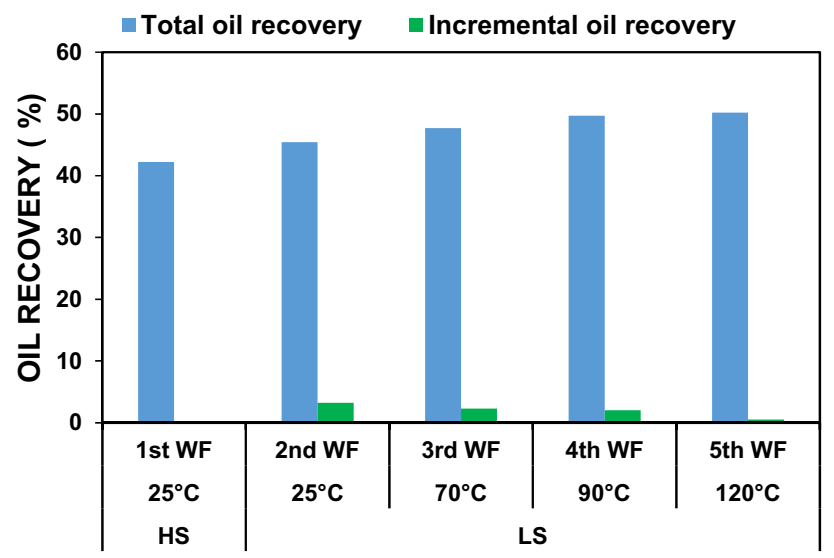

Fig. 9 Oil recovery test results for sandstone column\#1 (sand +illite)

Figure 13 shows the oil recovery test results for sandstone column\#2.

\section{General comment}

As can be seen from the results of the three columns, the desorption of $\mathrm{Ca}^{2+}, \mathrm{pH}$ upward shift, acetate detachments (which represent carboxylic acid in crude oil), and oil recovery tests were all approximately the same, which were in line with our theory of eliminating the role of clay from the effective factors that affect LS water flooding EOR. Sohrabi et al. (2015) conducted a systematic study to exclude the clay role as we did in this study. The incremental oil recovery that they had in the absence of clay was attributed to the formation of the micelles stemming from oil/brine interaction. In our previous work (Al-Saedi, Hasan et al. 2018), we measured the wettability alteration after flooding quartz column and quartz + clay column, and the results were the wettability altered towards more water wet in both columns. LS water was able to trigger the wettability of sand the same way that occurred in the

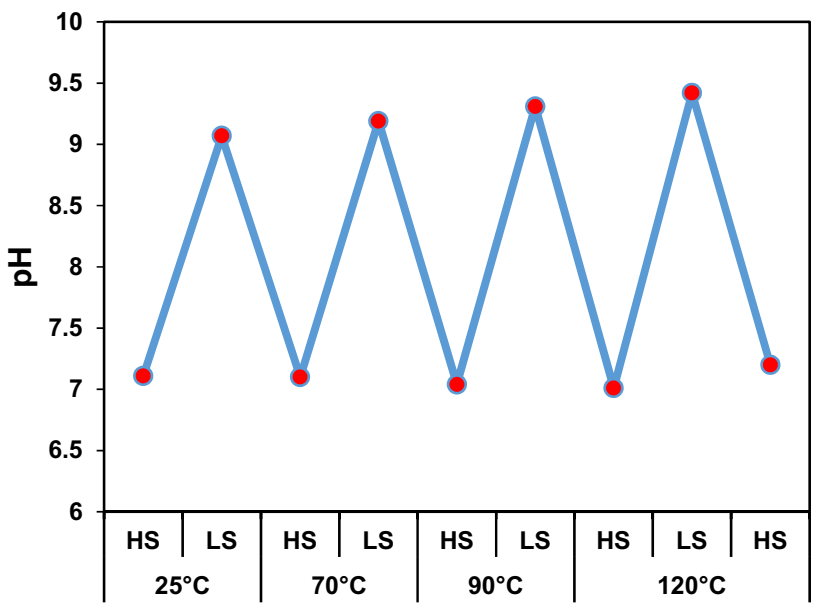

Fig. 10 Effluent $\mathrm{pH}$ from sand column\#2 (sand + kaolinite), at 25, 70, 90 , and $120^{\circ} \mathrm{C}$

presence of clays as shown in this reaction $\left[-\mathrm{COOCa}^{+}\right]$ $\left[>\mathrm{SiO}_{2}-\right]$.

\section{Conclusion}

The approach of this work is investigating the mechanism of incremental oil recovery using LS water using three different porous media were packed in chromatographic columns. Our study results reveal the important role that clay play in LS water-sandstone/LS water-crude oil. This study can provide insights to researchers when designing the LS water flooding and help researchers to decode the chemical mechanisms that control LS water flooding in sandstone. Clays participate in some of the oil recoveries, but quartz behaved the same way as clay. The results show that acetate detachments/ oil recovery increased during LS water flooding albeit in the absence of clay. In addition, $\mathrm{pH}$ and $\mathrm{Ca}^{2+}$ desorption from quartz surface was as high as in the presence of clays, indicating that an ion exchange occurred on the quartz surface. 

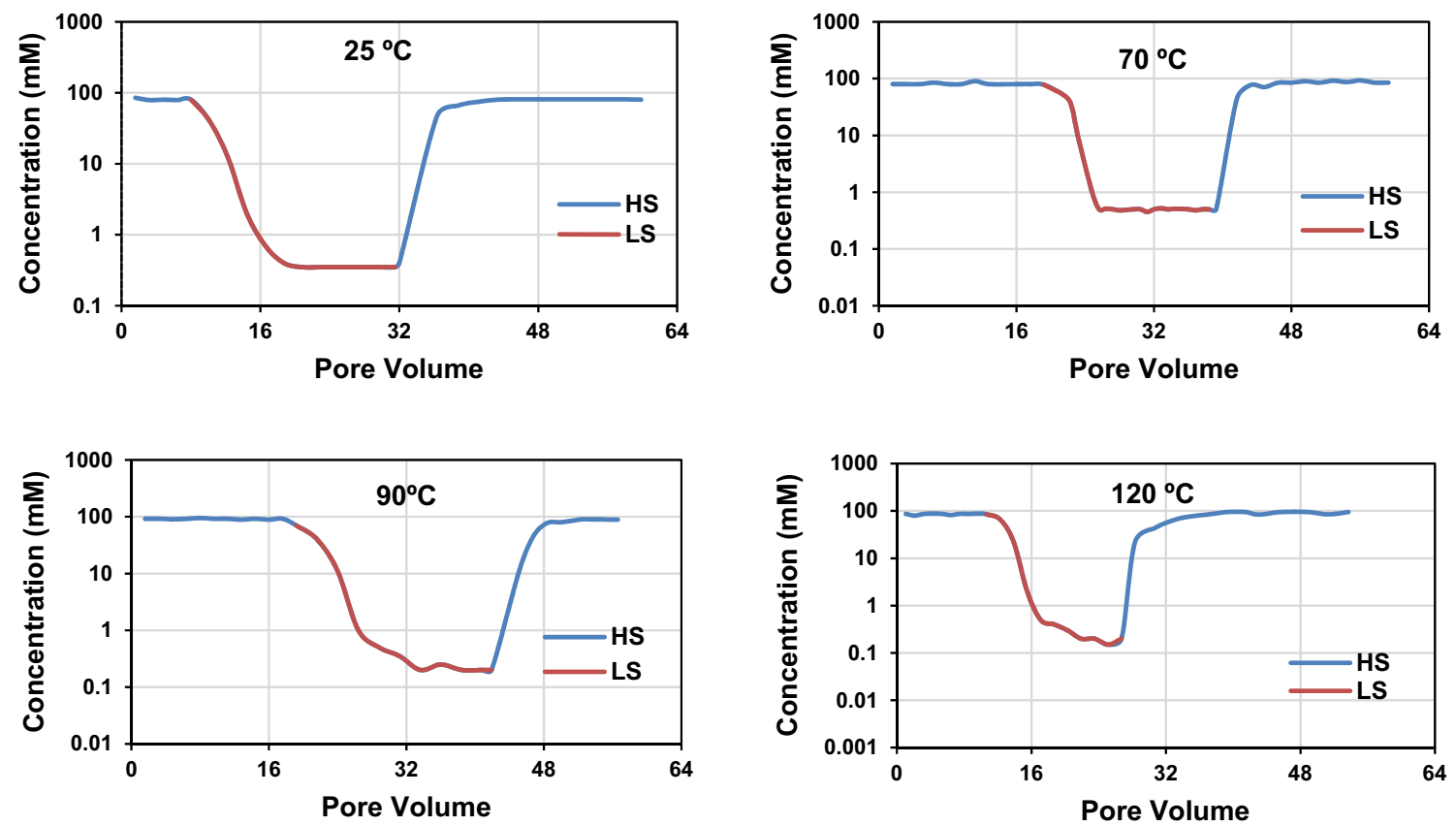

Fig. 11 Effluent concentrations of $\mathrm{Ca}^{2+}$ from sandstone column\#2 (sand+kaolinite), at $25,70,90$, and $120{ }^{\circ} \mathrm{C}$
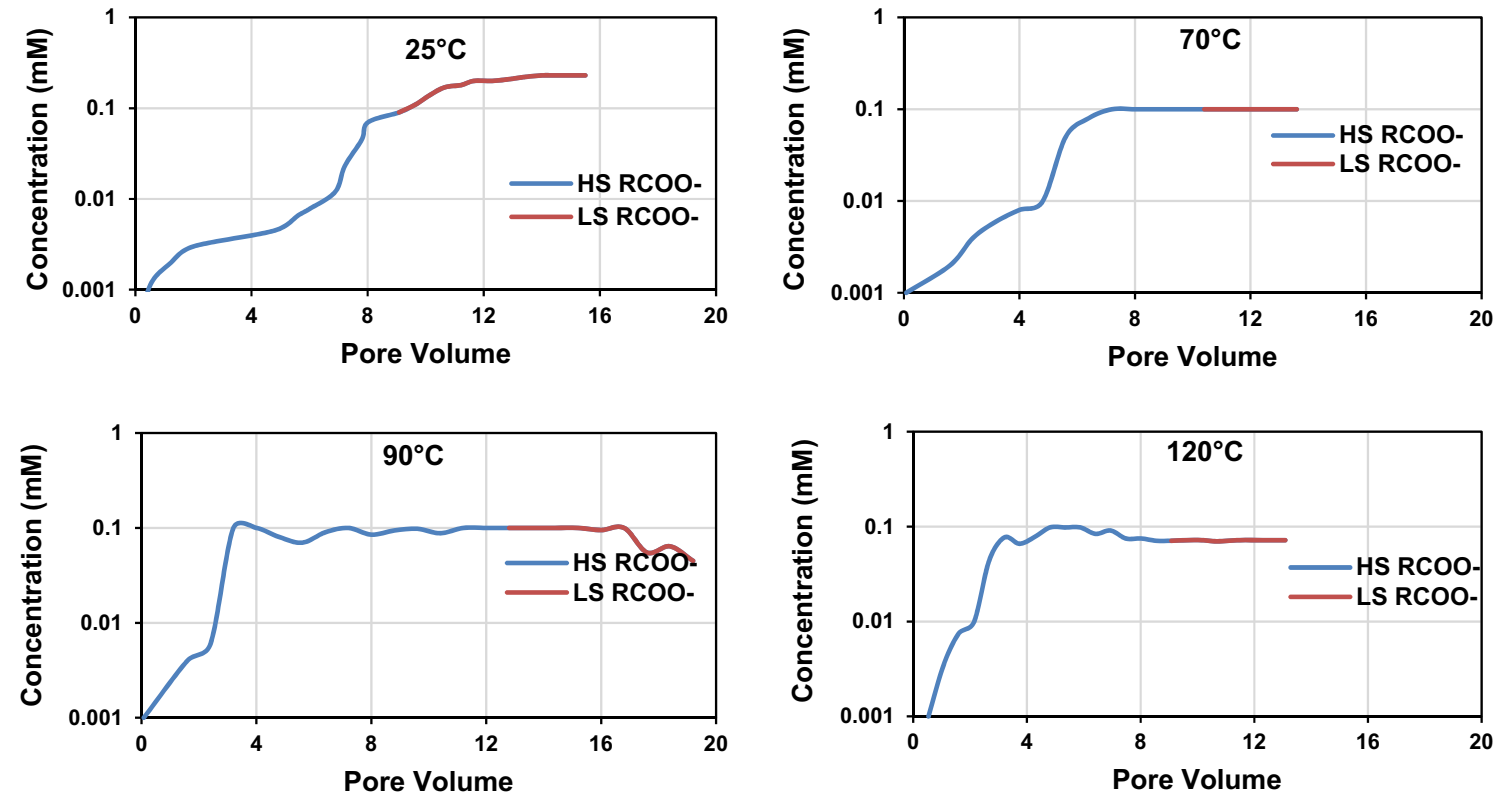

Fig. 12 Concentrations of $\mathrm{RCOO}^{-}$in first HS and LS water effluent for sandstone column\#2 (sand + kaolinite), at 25, 70, 90, and $120{ }^{\circ} \mathrm{C}$ 


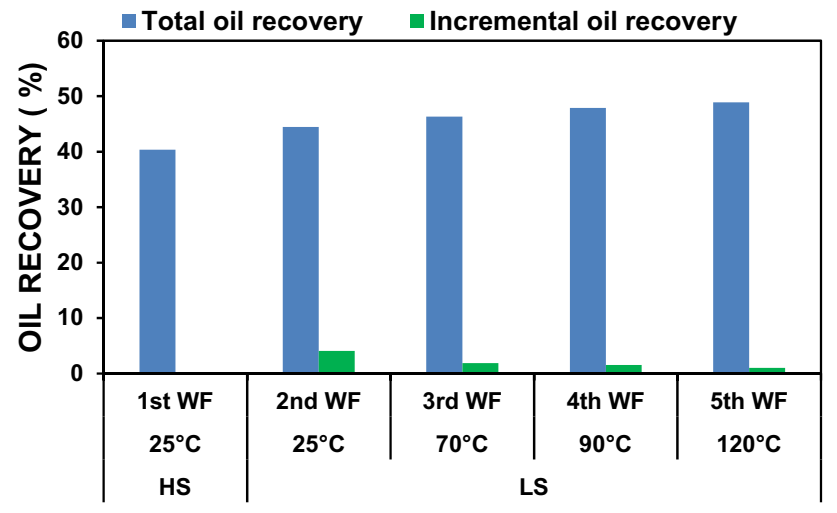

Fig. 13 Oil recovery test results for sandstone column\#2 (sand + kaolinite)

Open Access This article is distributed under the terms of the Creative Commons Attribution 4.0 International License (http://creativeco mmons.org/licenses/by/4.0/), which permits unrestricted use, distribution, and reproduction in any medium, provided you give appropriate credit to the original author(s) and the source, provide a link to the Creative Commons license, and indicate if changes were made.

\section{References}

Aksulu H, Håmsø D, Strand S, Puntervold T, Austad T (2012) Evaluation of low-salinity enhanced oil recovery effects in sandstone: effects of the temperature and $\mathrm{pH}$ gradient. Energy Fuels 26:3497-3503

Al-Saedi HN, Flori RE (2018) Enhanced oil recovery of low salinity water flooding in sandstone and the role of clay. Pet Explor Dev 45(5):1-6

Austad T, RezaeiDoust A, Puntervold T (2010) Chemical mechanism of low salinity water flooding in sandstone reservoirs. In: Proceedings of the 2010 Society of Petroleum Engineers (SPE) improved oil recovery symposium; Tulsa, OK, April 24-28, SPE Paper 129767

Barber LB, Thurman E, Runnells DD (1992) Geochemical heterogeneity in a sand and gravel aquifer-effect of sediment mineralogy and particle-size on the sorption of chlorobenzenes. J Contam Hydrol 9(1-2):35-54

Fogden A (2012) Removal of crude oil from kaolinite by water flushing at varying salinity and $\mathrm{pH}$. Colloids Surf A 402:13-23

Heidari P, Li L (2014) Solute transport in low-heterogeneity sand boxes: the role of correlation length and permeability variance. Water Resour Res 50(10):8240-8264

Lager A, Webb KJ, Black CJJ (2006) Impact of brine chemistry on oil recovery. In: Paper A24 presented at the 14th European Symposium on Improved Oil Recovery, Cairo, Egypt

Lager A, Webb KJ, Black CJJ, Singleton M, Sorbie KS (2008a) Low salinity oil recovery-an experimental investigation. Petrophysics 49(1):28-35
Lager A, Webb KJ, Collins IR, Richmond DM (2008b) LoSal enhanced oil recovery: evidence of enhanced oil recovery at the reservoir scale. In: Proceedings of the 2008 Society of Petroleum Engineers (SPE) Symposium on Improved Oil Recovery, Tulsa, OK, April 19-23, SPE Paper 113976

Li L, Salehikhoo F, Brantley SL, Heidari P (2014) Spatial zonation limits magnesite dissolution in porous media. Geochim Cosmochim Acta 126:555-573

Ligthelm DJ, Gronsveld J, Hofman JP, Brussee NJ, Marcelis F, van der Linde HA (2009) Novel waterflooding strategy by manipulation of injection brine composition. In: SPE 119835; EUROPEC/EAGE conference and exhibition. https://doi.org/10.2118/119835-MS

McGuire PL, Chatham JR, Paskvan FK, Sommer DM, Carini FH (2005) Low salinity oil recovery: an exciting new EOR opportunity for Alaska's North Slope. SPE Western Regional Meeting, 30 March-1 April, Irvine, California. https://doi.org/10.2118/93903 -MS

Minyard ML, Burgos WD (2007) Hydrologic flow controls on biologic iron(III) reduction in natural sediments. Environ Sci Technol 41(4): 1218-1224

Nasralla RA, Bataweel MA, Nasr-El-Din HA (2013) Investigation of wettability alteration and oil-recovery improvement by low-salinity water in sandstone rock. J Can Pet Technol 52(02):144-154

Rezaeidoust A, Puntervold T, Strand S, Austad T (2009) Smart water as wettability modifier in carbonate and sandstone: a discussion of similarities/differences in the chemical mechanisms. Energy Fuels 23(9):4479-4485

RezaeiDoust A, Puntervold T, Austad T (2011) Chemical verification of the EOR mechanism by using low saline/smart water in sandstone. Energy Fuels 25:2151-2162

Salehikhoo F, Li L, Brantley SL (2013) Magnesite dissolution rates at different spatial scales: the role of mineral spatial distribution and flow velocity. Geochim Cosmochim Acta 108:91-106

Sohrabi M, Mahzari P, Farzaneh SA, Mills JR, Tsolis P, Ireland $S$ (2015) Novel insights into mechanisms of oil recovery by low salinity water injection. Soc Pet Eng. https://doi. org/10.2118/172778-MS

Tang GQ, Morrow NR (1999) Influence of brine composition and fines migration on crude oil brine rock interactions and oil recovery. J Pet Sci Technol 24:99-111

Wang L, Li L (2015) Illite spatial distribution patterns dictate Cr(VI) sorption macrocapacity and macrokinetics environmental. Sci Technol 49(3):1374-1383

Yousef AA, Al-Saleh S, Al-Jawfi MS (2012) Improved/enhanced oil recovery from carbonate reservoirs by tuning injection water salinity and ionic content. In: SPE improved oil recovery symposium; Tulsa, OK, April 14-18, SPE Paper 154076

Zhang P, Tweheyo MT, Austad T (2007) Wettability alteration and improved oil recovery by spontaneous imbibition of seawater into chalk: impact of the potential determining ions $\mathrm{Ca}^{2+}, \mathrm{Mg}^{2+}$, and $\mathrm{SO}_{4}{ }^{2-}$. Colloids Surf A 301(1-3):199-208

Zinn B, Harvey CF (2003) When good statistical models of aquifer heterogeneity go bad: a comparison of flow, dispersion, and mass transfer in connected and multivariate Gaussian hydraulic conductivity fields. Water Resour Res 39(3):1-19 